\title{
Reconnaissance of 'Difference' in Cognitive Maps: Authenticating Happily Ever After in Julia Quinn's To Sir Philip with Love
}

\author{
Javaria Farooqui ${ }^{1}$, Rabia Ashraf ${ }^{2 *}$ \\ COMSATS University of Information Technology, Islamabad, Lahore Campus, Pakistan ${ }^{1}$; \\ Lahore College for Women University, Lahore, Pakistan ${ }^{2}$ \\ *Corresponding author: rabiaashrafbhatti90@gmail.com
}

\begin{abstract}
This study explores differences in individual cognitive mapping of the protagonists in Julia Quinn's novel, To Sir Philip with Love. A qualitative analysis of the maps, cartographed on physiological and psychological planes, finds them to be diverse in nature. A "difference" is developed, step by step, in the mental cognitive mapping of the female protagonist of Eloise and in the physical cognitive maps of the character the male protagonist, Philip. Nonetheless, the thesis lies in the inherent creativity caused by the collision of two varied cognitions. Analysis of these cognitions involves the creation of these characters according to the basic cognitive structure of the romance readers as well. After an investigation of the 'mindscaping' model, developed primarily around the main characters in To Sir Philip with Love, it is concluded that the positivity in the conflicting maps is established because of the genre of the novel, in which there is a need to channel the individual cognition towards the creation of a larger cognitive map for the readers, with authentication of Happily Ever After as its goal. Furthermore, this paper also locates the status of these findings within the romance narrative; authentication of HEA, works as a major building force in molding and constructing the authorial, fictional and reader cognition.
\end{abstract}

Keywords: Cognitive Mapping, Happily Ever After (HEA), romance reader response theory, mindscape.

\section{Introduction}

In the novel To Sir Philip with Love, cognitive maps of the two protagonists, charted on the physical and psychological plane, are found to be different. Yet, the collision caused by this difference, is creative rather than destructive in nature. The central thesis of this study rests in the conception, establishment and progression of two different cognitive spaces and the inherent creativity of their conflict that emerges as a result of this 'difference'. Mental mapping is a concept that started for the first 
time in cognitive psychology and was later adopted in varied disciplines like geography, history, and cultural anthropology. Coined by American psychologist Edward C. Tolman (1886-1959), cognitive mapping was understood through researching the sense of direction of rats. Tolman goes on to discuss the representation of spatial knowledge in the human brain (Tolman, 1948).

Cognitive mapping, in relevant academic literature, refers to such mental abilities that allow an individual to gather, organize, preserve, recall, and use information about a particular spatial environment (Tolman, 1948). Therefore, whenever spatial knowledge is represented in the human brain, the reasons may account to certain sense of cognitive mapping. Such maps show an individual's subjective understanding of spatial reality determined by his position at that period of time, angled perspective and his range of movement. Moreover, these maps represent world as it appears to an observer and this cognitive map allows the individual to get his bearings in his spatial setting. As a result, the person perceives the worlds as he believes it to be in accordance to the previously existing schemas of reality as developed through the cognitive maps.

However, the contention of this study rests in the differences or oddities in the formation of these cognitive mapping and mental recognition of the male and the female protagonist, particularly in the context of romance fiction. The thesis lies in establishing harmony out of the discordant understanding of the characters leading them towards the much celebrated happily ever after phenomenon of romances.

Romance genre as stated by Goris (2013) gets its very definition by its trait of 'happy ending.' For Goris, in any romantic fiction, the ideal scenario amounts to the protagonist meeting, falling in love and struggling to overcome the obstacles and are always with certainty rewarded with true love in the end in other words, they necessarily live happily ever after (Goris, 2013). Happy ending, as a result is the main focus of romance fiction as evident in To Sir Philip with Love. Similarly, Regis states that HEA- the acronym for Happy Ever After is never dependent upon chance and design in romances; in fact, it is one of the class apart and distinguishing characteristic of romance fiction (2003). These protagonists attain their love and enter into a happy life and this is where romance fiction essentially ends (Regis, 2003). In an opposing view, critics like An Goris and Janice Radway are of the view that romance readers want to look beyond HEA which is something lacking in To Sir Philip with Love as well. Quinn, like traditional romance fiction writers closes the book right after the union of the hero and heroine and readers are left to interpret a forever ideal situation. Goris writes in her paper, 'Many romance authors, including stars like Nora Roberts, Julia Quinn, Nalini Singh and others likewise report 
receiving plenty of request from readers...about characters and their happy end (2013).

\section{Theoretical Framework}

Tolman, opines that cognitive maps are linked to contain attributive values and interpretations (1948). Cognitive mapping is essential for decision making and spatial behavior as proposed by Lee through her conception of the phenomenon of cognitive mapping (Lee, 1964). For her, cognition is a day to day experience that provides an individual with certain codes to access and create conception of significant things or beings as observed. Cognitive maps are the repositories of knowledge and information that keep on growing and modifying as time passes by. Thus, cognitive maps are dynamic and not static sources of memory but clearly mobile (Kitchin, 1994). For, Smith and Wirth, any causal cognitive map represents an individual's beliefs concerning a particular domain at a point of time (1992). By domain they mean a point of interest of a particular individual at a particular time period. The internalized reflection of thought along with space on part of any individual is what gives form and shape to his or her mapping of mind. According to Bateson, cognitive mapping is a process and it is an ongoing entity. The end product of this process results in the formation of a cognitive map. A cognitive map is highly individualistic; it is the sum and substance of the world in which an individual lives. The world is very much the world as perceived by the individual. It is what he or she takes out of it and therefore, the cognitive map is a completely subjective idea- dependent on how an individual perceives and sees the world and space surrounding him. Cognitive maps, as stated by Wang have the capacity to largely change how an individual thinks and his decision-making ability (Bateson, 1996).

A cognitive map develops in number of ways. These ways are actually the abilities to store information. Thorndike and Goldin (1981), state that visualization ability is the skill to capture an image. The image is transformed and manipulated. Spatial orientation ability means to view the object in space. Visual orientation ability is the ability to remember particular information or object visually. This object attains a visual encoding. Field dependence and independence or cognitive restructuring ability is the ability to perceive objects as distinct from their context and generate an organization that is somehow slightly different from the original coded object in a particular context. Nadel and O'Keefe propound that there is immense difference between how we mentally present the cognitive map and the actual psychological and physical space that forms the cognition. They also hold that booth the 
psychological and the physical space are sort of complementing each other by nature and are highly related to each other. Physical space has been defined by them as "any space attributed to the external world independent of the existence of minds" (1978: p. 6-7). So, there is physical space, and there are mental maps of that space. A cognitive map can be defined in diverse ways; we ascribe to Neisser's (1976) a broad definition: "not pictures in the head, but plans for obtaining information from potential environments" (p.131). Hence, the basic definition of a mental map is that it provides a navigator who is moving in space about a sensory input through which the stimulus is formed. With a cognitive map which is a mental map of absolute space; the navigator can place itself within the framework and navigate directly among objects (O'Keefe \& Nadel, 1978: p.2).

Similarly, literature in the realm of cognitive mapping reveals that human beings have been frequently been characterized with cognitive maps (e.g. Tolman, 1948; Péruch et al. 1989; Herman et al, 1987). As Tolman's idea also adds that a cognitive map is also the ability to learn and make a stark difference between right and the ability to make short cuts between two points (Bennet, 1996).Other varied definitions include for example, Downs and Stea (1973) who equate cognitive maps to sets of shorthand symbols used and differ from group to group, individual to individual resulting from our previous experiences of life, biases and prejudices concerning reality and worldly phenomenon. However, it has been stated that these definitions and conceptions cannot be considered as the explanation of the idea of cognitive mapping as they do not deal with the behavioral predictions of the living beings and only talk about the nature and formation of a cognitive map (Bennet, 1996).

Cognitive mapping is a neuropsychological process, with both conscious and unconscious aspects. Cognitive maps can be generated with or without conscious intent. Although the cognitive map represents a set of processes of unknown physiological and controversial psychological nature, its effect and function are clear. Cognitive map or mindscape is the way with which it is possible to perceive the landscape. And in order to construct a mindscape, cultural and anthropological background of an individual is pertinent (Forte, 2002). The interpretation of a landscape depends variedly on individual perception, interaction with other entities and cultural learning. Without the development of a context, any communication in this regard would be null. Hence it is significant to create a virtual map based upon the 'difference' in a territory (Forte, 2002).

According to Bateson, something that does not get onto a trap is the physical territory. He maintains that 'if the territory were uniform, nothing would get onto the map except its boundaries; which are the points at which it ceases to be uniform against some larger matrix. What gets onto the map, in fact, is difference, be it a 
difference in altitude, a difference in vegetation, a difference in population structure, difference in surface, or whatever. Differences are the things that get onto a map' (Bateson, 1972, p.457). Therefore, it is pertinent, for this study to establish the nature of a 'difference.' Bateson (1972) remarks:

'A difference is a very peculiar and obscure concept. It is certainly not a thing or an event. This piece of paper is different from the wood of this lectern. There are many differences between them - of color, texture, shape, etc. But if we start to ask about the localization of those differences, we get into trouble. Obviously, the difference between the paper and the wood is not in the paper; it is obviously not in the space between them, and it is obviously not in the time between them. A difference, then, is an abstract matter.' (Bateson, p.465)

Hence 'difference' is what travels from the wood and paper to the retina and is then registered by the mind. Bateson further elaborates this point by stating an example of a blind man using a stick and tapping on the floor. Is the mental system of the blind man bounded at the handle of the stick? Or is it bounded by his skin? Does it start halfway at the tip of the stick? Such questions emerge out to be nonsensical. Bateson writes: 'The stick is a pathway along which transforms of differences are being transmitted... Some of these pathways happen to be located outside the physical individual, others inside; but the characteristics of the system are in no way dependent upon any boundary lines which we may superpose upon the communicational map' (Bateson, 1972: p.251, 495). Hence, for Bateson, only and only a difference can get into a map (1972). Cognitive map receives only the information of difference. This is exactly what Bateson propounds in his theory of knowledge. In his theory he explains how information is processed and the mechanism that it follows. Information is initially a neutral entity. The moment it interacts (difference), it changes into learning. And here, it becomes liable to stay and reside. With the increasing bar of differences, the bar of learning also keeps on increasing (Forte 2002: p.101). On the other hand, it is also stated that a cognitive map never gains completion and there are certain inaccuracies which are seldom or never corrected (Tversky, p.49).

It is also suggested that not all the information is processed and represented mentally but a certain scheme is devised to map it out. At times, some of the information is stored while other is ignored. One set of information might be rejected while other may be idealized (Tversky, p. 35). For Forte, the map is a sort of effect that sums up various differences and organizes all the information about the differences of territory (Forte, 2002: p.99). As far as the differences in cognitive maps are concerned, Langfield Smith and Wirth (1992), considering the case of differences of 
cognitive maps, explore how the cognitive maps of different individuals on the same phenomenon, object or idea undergo certain differences.

According to Welsh (2010), the convergence of the bond between the hero and the heroine leads to happiness and human beings perceive of happiness as a transient experience or the very end or goal of life. This rule has been advocated by writers of all times. For example, Aristotle, Mill and even Shakespeare for that matter as for all the laughs his comedy provides scene by scene as is evident in Much Ado About Nothing, Shakespeare also adheres to the convention that protagonists or the hero and the heroine of the world of fiction must live happily forever after, once the stage empties. British courtship novels feature marriage as the end of life, if only because that is where the narrated or dramatized actions come to a stop. Critics have also argued that fiction takes on the role of fairy tale life in which living happily ever after is just that, a fairy tale. However, the real life does not necessarily promise happily ever after. Only fairy tales or romance fiction does the promise of actually promising happiness after the completed action. Therefore, it is this happiness arising out of happily ever after that the writer looks for (Welsh, 2010).

\section{I: Cognitive Mapping in To Sir Philip with Love}

The current study is based on a qualitative research of the cognitive mapping in Julia Quinn's To Sir Philip with Love. In this novel, Quinn has built cognitive maps on an individual level wherein psychological and physical cognition of the protagonists is explored. Furthermore, she has created a larger cognitive map which encompasses the sensibility of the readers.

I would start with a discussion of the cognitive maps of the two main characters in the novel. To Sir Philip with Love is the story of a woman, Eloise Bridgerton, who starts correspondence with Sir Philip, husband of her deceased cousin. The novel is based in Regency time period and Eloise is a spinster of twenty eight years of age. She has never met Sir Philip but has carved his image out of the letters he has written to her. She has rejected several proposals but agrees to take up his proposal of marriage without even once meeting him in person. Eloise's cognitive maps are cartographed primarily on a mental level whereas Sir Philip's cognition registers the physical differences. In the very beginning, Eloise clearly highlights the mental 'difference' between Sir Philip and any other man. "Sir Philip, she felt, belonged to her. She had tied his letters with a purple ribbon hers. 'He was her secret. Hers. And because she'd never actually met him, she'd been able to create him in her mind, using his letters as the bones and then fleshing him out as she saw fit' (Quinn, p.25). A cognitive map is hence being formed on two levels. The heroin has registered a 
difference and her cognitive mapping would be built on it. On the second level, Quinn has created a cognitive map for her readers with the use of phrases like 'fleshing him out as she saw fit' and 'of her imagination.' The choice of these phrases raises the margin of doubt in the minds of readers, hence creating a mental map for the readers where, in the beginning, the heroin's imagination would collide with her physical reality. An exact cognitive mapping would show a series of rise and fall in the level of expectations, of the characters and the readers both, based on the differences.

Like Eloise, Sir Philip's cognitive mapping also marks the differences, but these are of a rather physical nature. Eloise expected him to show the same level of attachment to her letters as she had lately developed for his letters. However, Sir Philip's cognition has not marked them as a 'difference' in the way Eloise has: "Philip's lips parted in surprise. "You saved my letters?" "Of course, Didn't you save mine?"/ $\mathrm{He}$ blinked. "Uh..."/She gasped. "You didn't save them?"/ Philip had never understood women and half the time was quite willing to put aside all current medical thought and declare them a separate species altogether..." (Quinn, p.49). In this exchange of opinions, Eloise's cognition is registering an alteration in her mental 'difference' because of the physical nature of Sir Philip's cognition. When he 'blinks,' her cognitive map, which had earlier marked him as a different man, alters. Hence, she 'gasps.' Later on, Quinn clarifies the physicality of Sir Philip's cognitive maps. He has also marked Eloise 'different,' but on a physical plane: “ He looked at her assessingly, his eyes searching hers until she squirmed in her seat. "You are not what I expected, Miss Bridgerton." "What did you expect?" Eloise countered. (He said)...quite bluntly, "I didn’t expect you to be so pretty" (Quinn, p.75).

So, when Sir Philip marks his differences by a physical parameter, the pathways of information in his cognitive system collide with those of Eloise. At this point it would be pertinent to bring in the Batesonian distinction between external and internal pathways. He says that we commonly perceive of the external world as somehow separate from an internal 'mental world but the mental world- the mindthe world of information processing has no delimitations of the skin' (Bateson, 1972). The pathways of information which register the differences in Eloise's cognition are less physical and when they collide with the physiological cognition of Sir Philip, they create instead of destroying. However, the creativity is developed at a later stage and the novel focuses more on cartographing the 'difference.'

The novel contains various instances where Sir Philip's physiological cognitive map runs alongside Eloise's cognition without colliding with it. The collision doesn't happen when he proposes marriage to her: "Which one do you want," she clarified, her voice still soft. "A wife or a mother?" "Both," he said. "I should think that was 
obvious." "Which one do you want more? Finally, he just offered her a helpless shrug and said, "I'm sorry, but I don't know how to separate the two." she murmured. "I expect you are right" (Quinn, p.79). Eloise's mental cognitive mapping has made her aware of the difference in 'differences,' whereas the physicality of Sir Philip's nature deters him from catching another pathway of information. In the following excerpt, Quinn has clarified this cognition obstacle. Sir Philip's cognitive mapping system has detected a 'difference' outside his physiological boundaries but he refuses to acknowledge it as a 'difference' within his cognition. "He'd needed more. He'd needed Eloise" (Quinn, p.232-33). When he recognizes that he needed more, his cognition is leading him towards an acceptance of the mental 'difference.' But he immediately channels the cognition, first towards the person of 'Eloise,' which constitutes both the mind and the physical self, and in the second step, takes it purely towards a physiological direction. Later on, in the plot, even when his physical self finds contentment, his cognition follows a physiological pattern: "And if sometimes his wife looked at him as if she wanted him to say something different or do something different- well, he chalked that up to the simple fact that he was a man and she was a woman, ... since he wasn't constantly left guessing what was expected of him" (Quinn, p.297).

It would be pertinent at this point to mention the 'initial input' perspective. According to Wang (1996), an initial input to a cognitive mapping neural network results in a series of neural networks, making the finite map. This initial input to the neural network stands for a particular decision applied to a target system. If an initial input generates two cognitive mapping neural networks as a response, they are concluded to be similar which means that there is meagre cognitive difference between the two cognitive maps which are the bases for the two neural networks and resultantly the target systems have the similar outcome to the same decisions (Wang, 1996). As discussed earlier, the initial input in Sir Philip's cognition is of primarily a physical nature. The first input he received was the recognition of her physical beauty. The physiological cognitive map then formed continues to develop throughout the novel. He has not fleshed her out of the words in her letters, like Eloise has. Instead, he has not formed any opinion of her based on her letters. The mental cognizance does exist but it is not as sharp as the physical cognition. Quinn has highlighted this fact in the beginning. Sir Philip's 'idea' of Eloise, before meeting her is quite blank and functional: "The mysterious Eloise Bridgerton wasn't really so mysterious...And she'd been corresponding with a complete stranger for a year; surely she was a little desperate... What more could she want?" (Quinn, p.33)

This elemental physiological cognition is very different from the psychological and sentimental cognition of Eloise. Sir Philip's cognition is physical, that is why before the reception of a physical input, and he has formed only a very vague image of 
Eloise. He has no 'idea' of Eloise formed out of mere words. Herein lay the primary difference between these two cognitions. Both of them were communicating with each other through letters, which I would consider to be a part of mental cognitive mapping system. For Eloise, the letters are important because her cognition is psychological. However, Sir Philip's cognition is far more physical. His cognitive mapping technically starts when he meets her, in person. At that time, his cognition marks the beauty of her eyes and that is the initial input which his system receives: "He stopped short; stumbled, even. Because the woman standing in his entry hall was young, and quite pretty, and when she looked up to meet his gaze, he saw that she had the largest, most achingly beautiful gray eyes he'd ever see. He could drown in those eyes" (Quinn, p.37). Quinn has specifically used the word 'achingly,' which marks the physicality of his cognition. Almost immediately after this initial input, he confesses that he has not kept Eloise's letters as she has saved his. That incident would further establish his physiological state of cognition.

The initial input in Eloise's cognition, however, is psychological and continues to be so even after she accepts the physical aspect of her relationship with Sir Philips. Her 'difference' is based on the image her mind has made. As the plot develops, her cognition marks it more clearly. Even after being married to Sir Philip and being happy physically, her cognitive mapping keeps on processing the 'difference' cartographed on a psychological plane:

'And, in truth, she was in many ways still learning who her new husband was... she didn't know his experiences, his opinions, what had happened in his life to make him the man he now was. She tried, sometimes, to draw him out in conversation, and sometimes she succeeded, but more often than not, her attempts melted away. Because he never seemed to want to talk when he could kiss.' (Quinn, p.287-88)

There are visible signs of frustration in her behavior when the 'difference' marked by her cognition goes beyond her reach. She needs to build a psychological peace and her goal is to reach the cognitive signpost of love. Tolman, who first introduced the term 'cognitive map' in 1948, identified three postulates in the cognitive mapping theory. First one is that all organisms, including humans, are characterized by the propensity to pursue goals in whatever environment they happen to be placed. Secondly, these goals can only be attained insofar as the organism has succeeded in synthesizing a functional subjective representation of that environment from the fragmentary bits of information received through previous contacts with the object world. And most importantly, general knowledge is neither present in the organism nor in the environment, but it is a result of the organism's highly selective construction of such representations in an ongoing, dialectical interchange between 
itself and the environment (Tolman, 1948). So, the goal, which Eloise has created, after synthesizing a functional subjective representation of her psychological cognitive environment, is love. The bits of information, received through previous contacts with the object world, were Sir Philip's letters. Her frustration stems out of the fact that her psychological cognition is clashing with the physiological cognition of Sir Philip.

\section{II: Creativity in the Collision of Cognitive Maps}

After analyzing the cognitive maps of the protagonists in To Sir Philip with Love, it would be interesting to identify their differences according to a scale developed by Langfield-Smith and Wirth (1992). The cognitive maps of two individuals can have three types of differences. The first one, being the 'existence or non-existence of elements,' occurs when one individual regards certain aspects within a domain as important, which the other individual does not. We can see that in the case of cognitive maps under discussion, psychological element does not exist in the cognition of Sir Philip. His pathways of information do not accept the mental processing present in the cognitive mapping of Eloise. Second type of difference is based on the 'existence or non-existence of beliefs.' In the cognitive maps of Eloise, a belief in love as a goal is present. However, Sir Philips' cognition shows an absence of it. His goals streams towards the physical channel. His is happy when he finds a wife who is perfect for his children and who satisfies him aesthetically on an elemental level. The fact that his cognition does not register the belief in love, cements the cognitive difference between him and Eloise. Langfield-Smith and Wirth (1992) have elaborated this type of difference further by adding that when "this difference exists there would be a non-zero number in a cell in one individual's adjacency matrix, but the corresponding cell in the other matrix would contain zero" (p.1140). Hence the zero in Sir Philip's matrix is colliding with the non-zero in Eloise's adjacent matrix, causing her frustration. 'And all she could think was- She hadn't pushed. Good heavens, what had she done but come to him with a concern about his children? Was it so very wrong to actually want to speak rather than race off to the bedroom? ...She had never felt so alone in all her life.' (Quinn, p.307)

The third difference, however, is even more apt in a study of the cognitive maps in To Sir Philip with Love. This difference is recorded when there are beliefs that are identical but are held with differing strengths. In this case, two individuals proclaim identical belief but one holds this belief more strongly than the other...this type of difference would be evident when a cell in one matrix (being at the intersection of two elements that are common to both maps) contains a non-zero number, and in the 
other matrix the corresponding cell contains a different non-zero number. The element of attraction is common to both maps. Sir Philips reaches this attraction following the physiological cognitive map whereas Eloise has cartographed a psychological one. The intersection between these two 'different' elements is evident at the climax of the novel when Sir Philip lays bare the guilt and remorse plaguing his past matrimonial relationship and confesses his love for Eloise in words. The 'difference' in cognition is accepted by both individuals. The author has not allowed the' difference' to play a destructive role in the relationship of the protagonists. A creative collision is created by Sir Philip's recognition of the psychological differences in Eloise's cognitive maps. He understands the importance of words in her cognition. In all the previous scenes, Sir Philip's physical cognition has refused to acknowledge the need of conversation. It was the basic point at which Eloise's mental processing detected a difference. However, at this point, he makes it clear that he is stopping to tell her that he loves her, not because his mapping technique has become different, but because his physiological cognitive pattern has collided with an accepted the existence of her mental cognition. He had to stop, not exactly wanted to stop. And Eloise, on her part, is able to accept the physicality of his cognitive maps. Her lips curve in a smile at the physicality of his thought process. Both individuals know what the other is thinking and here lies the climatic union of the two cognitive maps. They are aware of the existence and the difference of the other map, but they are willing to synthesize rather than annihilate the difference. This creativity might seem imposed after exploring the 'difference' in their cognitive mapping but it must be kept in mind that the readers of this particular novel would be looking for the promise of a happy ending. The individual cognitive maps formed by the author have to confirm with the cognitive maps of the readers. The readers of popular romance genre would be able to recognize the 'difference' in the cognitive maps of the protagonists but their 'goal' would be reading about the creative collision of the zero and non-zero elements.

\section{Conclusion}

It can be concluded that the 'difference' between the individual cognitive maps in Quinn's To Sir Philip with Love, is cartographed to highlight the creativity in the collision of these differences. The novel embodies, a great deal of romance fiction features in it where mainly the two protagonists of opposite genders meet but are unable to find the chemistry which is a famous trait of romance fiction. Their thought process creates a cognitive map which both of the protagonist make according to their own take on the identity formation of each other. As a result, a difference in cognitive mapping is created when different is achieved and experienced than expected. Quinn make this situation interesting as following the basic and glaring 
feature of romances the protagonist must meet, be united and live Happily Ever After, this however becomes the real challenge. Quinn artistically portrays how apparently destructive difference in cognitive mapping leads towards a collision that is creative and embraces the romance HEA.

\section{References}

Alexander, W. A., (2010) Living Happily However After. Social Research. The New School, 77 ( 2). 491-522.

Bateson, G., (1972) Steps to An Ecology of Mind. Chicago: The University of Chicago Press. Bennet, A. T. D., (1996) Do Animals Have Cognitive Maps? The Journal of Experiment Biology. Great Britian.

Downs, R. M. \& Stea, D., (1973) Cognitive maps and spatial behavior: process and products. In R. M. Downs \&D. Stea (Eds.), Image and environment: cognitive mapping and spatial behavior. Chicago: Aldine Publishing Company.

Forte, M., (2002) Mindscape: ecological thinking, cyber-anthropology and virtual archeological landscapes. Virtual archeology, Proceedings of the Vast Euroconference Arezzo, 24-25 (ed. By F. Niccolucci) BAR International Series, Oxford.

Goldin, Sarah E. \& Perry W. T., (1981) An Analysis of Cognitive Mapping Skill. Santa Monica, CA: RAND Corporation.

Goris, A., (2013) Happily Ever After...And After: Serialization and Popular Romance Novel. Americana. The Journal of American Popular Culture 1900 to Present. 12(1).

Kim Langfield-S, \& Andrew W., (1992) Measuring Differences between Cognitive Maps. The Journal of the Operational Research Society, 43 (12), 1135-1150.

Kitchin, R. \& Freundschuh, S., (2000) Cognitive Mapping: Past, Present and Future, Routledge, London.

--- 1994., Cognitive maps: what they are and why study them. Journal of Environmental Psychology, 14, 1-19.

Lee,Sue- A., (1964) Cognitive Mapping Research. Cognitive Mapping Research. Architectural Psychology Research Unit, Kingston Polytechnic, Kingston Upon Thames, Surrey. KTI 2QJ. U.K.N. date.

O'Keefe, J., \& Nadel, L., (1978).The hippocampus as a cognitive map. Oxford, England: Oxford University Press.

Pearce, L., (2011) Romance and Repetition: Testing the Limits of Love. The Journal of Popular Romance Studies. 2 (1).

Perry. W T, \& Sarah .E G., (1981) Ability difference and Cognitive Mapping Skills. The United States Army.

Quinn, J., (2003) To Sir Philip, with Love. NewYork: Harper Collins Publishers Inc., 2003.

Radway, J., (1984) Reading the Romance: Women, Patriarchy and Popular Literature, Chappel Hill: $U$ of North Carolina P.

Regis, P., (2003) A Natural History of the Romance Novel. University of Pennsylvania Press.

Tolman, Edward C., (1948) Cognitive Maps in Rats and Men. The Psychological Review. 55.

Tversky. B., (1981) Distortions on Memory for Maps. Cognitive Psychology. 13, 407-33.

Wang, S., (1996) A Dynamic Perspective of Differences between Cognitive Maps. The Journal of Operational Research Society , 47 (4).

Wirth, A, \& Kim Langfield-S., (1992) Measuring Differences between Cognitive Maps. The Journal of the Operational Research Society 43 (12), 1135-1150. 